\title{
O DELU KNIIŽNICE ODDELKA ZA GEOGRAFIJO FILOZOFSKE FAKULTETE
}

\author{
Tatjana Šfrer* - Janja Turk**
}

IZVLEČEK

UDK 02:91 (497.12)

Članek na kratko predstavlja razvoj in delo knjižnice Oddelka za geografijo Filozofske fakultete od zað̌etka do današnjih dni.

ABSTRACT

UDC 02:91 (497.12)

ON THE WORK OF THE GEOGRAPHICAL LIBRARY AT THE DEPARTMENT OF GEOGRAPHY

The articlc presents the development and work of the geographical library at the Department of Geography from its begining up to the present.

Po prvi svetovni vojni 1.1919 smo Slovenci koneno dobili svojo slovensko univerzo v Ljubljani, v njenem sklopu pa je že istega leta zaživela tudi Filozofska fakulteta. Na njen poziv je v naslednjem letu Hrvat prof. dr. Artur Gavazzi organiziral Geografski institut, uredil dodeljene mu prostore $v$ drugem nadstropju dotedanjega deželnega "dvorca", sedanjega g!avnega poslopja Univerze Edvarda Kardelja na Trgu revolucije, tako da je v zaðetku februarja 1. 1921 že lahko priðel z delom. Dr. Gavazzi je s tcm položil temclje notranje organiziranosti samega instituta in hkrati poskrbel tudi za institutsko knjižnico, kartografsko zbirko in laboratorij. Te prve dneve organiziranja in delovanja slovenske visokošolske geografije je sam opisal v kratkem zapisu iz 1. 1922 (Gavazzi, 1922). V njem poroca, da je Geografski institut sprva dobil za svoje delovanje na razpolago eno vecjo in tri manjše sobe. $\mathrm{V}$ veliki sobi je bil seminar, v njej pa sta bili tudi dve veliki omari za knjige. Knjižnica je tedaj poleg "1.200 najvažnejših dei" (Gavazzi, 537) imela tudi naslednje strokovne revije: "Petermanns Mittcilungen" (kompletne), "Kartogr. Zeitschrift" (kompl.), "Zeitschrift" Geografskega društva v Berlinu (kompl.), "Mitteilungen" in "Abhandlungen" Gcografskega društva na Dunaju (kompl.), "Meteor. Zeitschrift" (kompl.), "Bulletin" Oceanografskega instituta v Monacu (kompl.), "Revue" za hidrobiol. in hidr. (kompl.), Hettnerjev "Geogr. Zeitschrift", "Annalen f. Hydr. u. marit. Meteor.", "La Geographie" (20 letnikov je podarilo Parißko geografsko društvo), "Annales de geographie" (podaril založnik), "Geographical Journal" (poslalo zastonj Londonsko geografsko društvo), potem Behm-Wagnerjev "Jahrbuch" (kompl.), pa "Bibliotheca geographica" (kompl.). Zelo

* Bibliotekarski svetovalec, Oddelek za geografijo, Filozofska fakulteta, Aక̌kerčeva 12, 61000 Ljubljana, YU.

** Bibliotekar specialist, Oddelek za geografijo, Filozofska fakulteta, Aškerčeva 12, 61000 Ljubljana, YU. 
veliko svojih publikacij je podarila bosanska vlada ("Glasnik", "Mittelungen" in dr.), hrvaška vlada ("Geologijske karte" in dr.), drž. statistika v Beogradu, stat. urad v Zagrebu itd.) (Gavazzi, 537). Kot vidimo, se je v teh prvih Casih nateklo veliko revialnega (in verjetno tudi knjižnega) gradiva $v$ institutsko knjižnico $z$ darovi. Institutska kartografska zbirka pa je poleg Perthesovih kart za predavanja hranila tudi "mnogo specialnih, generalnih, pomorskih in geoloskih kart" (Gavazzi, 537), ki so jih imeli spravljene kar $v$ dveh vexjih predalih dveh večjih miz, ker zanje niso dobili posebne omare. V eni od manjših sob je bila dr. Gavazzijeva pisarna z njegovo lastno biblioteko, $\mathbf{v}$ drugi je bil kemix̌ni laboratorij, "kjer so določali sestavine navadne vode in kamnov oziroma vzorcev z jezerskega dna" (Gavazzi, 537). V tretji sobi so visele stenske karte, hkrati pa so $\mathrm{v}$ njej tudi razvijali fotografije in opravljali razne fizixnogeografske poizkuse.

Tolikšen obseg je obdržal Geografski institut vsa predivojna leta, med drugo svetovno vojno in po njej, ko so mu končno dodelili š dve sobi $v$ prvem nadstropju iste stavbe. Medtem se je namrę že poveð̌alo število institutskega osebja, knjižni fond pa je že tako porastcl, da smo ga hranili na knjižnih policah $v$ več sobah in ડe v nekaj omarah, ki so stale kar na hodniku. Našo prostorsko stisko je končno 1.1961 resila dograditev sedanjega poslopja Filozofske fakultete na Askerと̌vi ulici v Ljubljani, kamor smo se preselili tudi geografi. Tu je tudi rała oddelěna (prej institutska) knjižnica koňno dobila ustrezne prostore: dva velika za hrambo knjižnega građiva oz. zemljevidov ter tri manǰ̌e sobe za kataloge, bibliotekarje in za oddeléno citalnico za studente. Toda v obdobju 1961-1988 je sttevilo zvezkov in zemljevidov zopet tako narastlo (za 34.152 enot, od 31.126 na 65.278 ), da postaja prostorska stiska vse ve ${ }^{2}$ ja. Zaenkrat smo jo delno rcక̌ili z novimi omarami na hodniku, kamor bomo spravili starejse knjige in revije.

\section{KNJIŽNI FOND}

$\begin{array}{llllll}\text { Leto } & \text { v celoti } & \begin{array}{l}\text { knjige, } \\ \text { scparati, } \\ \text { atlasi }\end{array} & \begin{array}{l}\text { revije } \\ \text { (letniki) }\end{array} & \begin{array}{l}\text { scminarske } \\ \text { diplomske } \\ \text { naloge }\end{array} & \begin{array}{l}\text { zemljevidi, } \\ \text { diapozitivi }\end{array} \\ 1979 & 53.722 & 13.644 & 8.415 & 2.016 & 29.647 \\ 1980 & 55.442 & 14.179 & 8.579 & 2.078 & 30.606 \\ 1981 & 57.051 & 14.642 & 8.799 & 2.206 & 31.404 \\ 1982 & 58.508 & 15.286 & 9.012 & 2.288 & 31.922 \\ 1983 & 59.699 & 15.771 & 9.195 & 2.352 & 32.381 \\ 1984 & 60.765 & 16.257 & 9.397 & 2.412 & 32.699 \\ 1985 & 61.874 & 16.769 & 9.616 & 2.449 & 33.040 \\ 1986 & 63.018 & 17.249 & 9.879 & 2.501 & 33.389 \\ 1987 & 64.218 & 17.713 & 10.095 & 2.536 & 33.874 \\ 1988 & 65.278 & 18.169 & 10.348 & 2.573 & 34.188\end{array}$


LETNI PRIRAST ( $v$ celoti)

$\begin{array}{ll}\text { Leto } & \begin{array}{l}\text { knjižno } \\ \text { gradivo }\end{array} \\ & \\ 1979 & 710(2.859) \\ 1980 & 761(1.720) \\ 1981 & 811(1.609) \\ 1982 & 939(1.457) \\ 1983 & 554(1.191) \\ 1984 & 748(1.066) \\ 1985 & 768(1.109) \\ 1986 & 795(1.144) \\ 1987 & 715(1.200) \\ 1988 & 746(1.060) \\ & \end{array}$

TEKOČE REVIJE

$\begin{array}{ll}\text { REVIJE } & \text { IZPOSOJENO } \\ \text { (po naslovu) } & \text { KNJIŽNO } \\ & \text { GRADIVO IN } \\ & \text { ZEMLJEVIDI }\end{array}$

230
208
177
214
162
204
214
216
189
234

9.632

12.039

17.930

14.143

15.642

15.169

17.434

17.107

17.746

19.948

V zadnjih desetih letih (1979-1988) je nas celotni fond porastel s 53.722 na 65.278 enot, tako da sodi knjižnica Oddclka za geografijo med največje na Filozofski fakulteti in je obenem tudi najve`ja geografska knjižnica v Sioveniji. Kot je razvidno iz tabelc, smo ob koncu 1. 1988 imcli $18.169 \mathrm{knjig}$, separatov in atlasov, 10.348 letnikov predvsem gcografskih revij, 2.573 seminarskih in diplomskih nalog ter $34.188 \mathrm{zemlje-}$ vidov in diapozitivov.

Pri tem naj omenimo, da nekaj od tega gradiva pripada knjižnici Geografskega drustva Slovenije, ki je nastala istocasno kot drustvo samo (1. 1922) ter se je tekom let

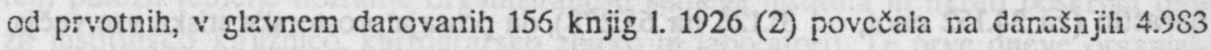
enot (1.112 knjig in 3.871 letnikov revij). Njen fond se je večal predvsem na racun zamenjave društvenega glasila Geografskega vestnika z mnogimi domačmi in tujimi gcografshimi revijami (1. 1926 so posiljali Geografski vestnik na 31 nasiovov (2), l. 1930 ra 92 (3) in 1.1934 že 119-im rasiovnikom doma in v tujini (4). Gcografsko drtకtvo Slovenije je imelo v svojem poslovnem oz. upravnem odboru dolga leta (od 1 . 1922-1968) tudi posebnega odbornika, knjižni๔arja. Vendar že od 1.1969 dalje druŠtevna knjižnica ne raste veð, ker je tedaj Oddciek za geografijo priðcl cdkupovati Geografski vestnik od Geografskega drustva Slovenije in s tem prevzel vso skrb za zamenjavo tega glasila $\mathrm{z}$ raznimi domaximi in tujimi geografskimi revijami.

Tako smo zadnjo Stevilko Geografskega vestnika za 1. 1988 razposlali na 131 naslovov in od tam prejeli prav tolikšno కttevilo raznih geografskih casopisov. Od tega je కło 36 izvodov po Jugoslaviji (SRS - 17, SFRJ - 19), 95 pa v inozemstvo (Evropa - 84, ostali svet - 11). V zameno pa zadnja leta pošiljamo tudi Dela Oddelka za geografijo Filozofske fakuliete in to 26 zvezkov po Jugoslaviji (SRS - 12, SFRJ - 14) in $51 \mathrm{v}$ inozemstvo (Evropa - 45, ostali svet - 6). Skupaj smo tako letos razposlali iz naకe knjižnice v zameno 208 izvodov citiranih revij. Zanje prejemamo stevilne kvaiitetne geografske in njim sorodne revije iz skoraj vseh cvropskih držav (najveð iz Zvezne 
republike Nem $x_{i j e}$ ), nekatere pa tudi iz ostalih kontinentov (z izjemo Afrike). Z njimi se v naši knjižnici zbira bogato, aktuaino strokovno-znanstveno gradivo, ki je neprecenljive vrednosti za našo stroko. Seveda moramo nekatere pomembne inozemske geografske revije tudi kupovati preko založb (1. 1988 - 20 naslovov).

Veliko skrb posve đamo $\mathrm{v}$ knjižnici tudi pravilni izbiri pri narođanju predvsem inozemskih strokovnih knjig in atlasov. Zato sistematixno zasledujemo recenzije $\mathrm{v} t u j \mathrm{~cm}$ revialnem tisku, razne bibliografije in knjigotrške kataloge, da bi oskrbeli knjižnico vsaj $\mathrm{z}$ vsemi temeljnimi, najpomembnejšimi ter za naše konkretne potrebe najbolj aktualnimi domačimi in tujimi deli.

V oddelCni knjižnici hranimo tudi seminarske naloge in diplomska dela (1. 1988 že 2.573 izvodov) studentov geografije od prvih let visokosolskega studija geografije v Ljubljani do danes.

V sklopu knjižnice Oddelka za geografijo je tudi kartografska zbirka. Prvotna inštitutska zbirka je bila zbirka pretežno topografskih, pomorskih, geoloskih in stenskih kart, ki so jih uporabljali pri predavanjih. Iz leta v leto pa je kartografska zbirka Stevilæno in vsebinsko rasla in ob koncu 1. 1988 stela že 32.628 najrazlixnejsih kart. Zadnja leta prirast kartografskega gradiva presega 300 izvodov kart letno. Vexji del kart kupimo, ceprav tudi darovi niso redki. Pred leti je Vojnogeografski inštitut iz Beograda podaril zbirko topografskih kart meril $1: 50.000,1: 100.000$ in $1: 200.000$ za celotno ozemlje Jugoslavije. Žc nekaj let pa sodelujemo tudi z osrednjima kartografskima institucijama v Sloveniji - Gcodetskim zavodom SRS in Inštitutom za geodezijo in fotogrametrijo, kateri nam redno, brezplakno poßiljata vsak primerek novo izdelane karte. Za potrebe pedagoß̌kega in raziskovalnega dela sistematicno zbiramo tiskane karte, ki prikazujejo ozemlje Slovenije bodisi splošne pregledne karte ali tematske karte. Povecujemo tudi zbirko kart s področja Jugoslavije in ostalih delov sveta.

Obiskovalci kartografske zbirke so pretežno studenti našeģa oddelka, katerim je karta nujen pripomođek pri študiju kot tudi izdelavi raznih pisnih nalog. $Z$ veseljem pa ugotavjamo, da je vedno veđ obiskovalcev tudi iz vrst Studentov ostalih strok na univerzi, ali drugih, ki potrebujejo karto kot pripomocek na potovanju ali pri strokovnem delu. V letu 1988 smo 5.476 obiskovaicen izposodili 5.230 kart. Zaradi vedno vexjega కttevila kart in uporabnikov postaja prostor, ki je namenjen kartografski zbirki ( $v$ njem pa delujejo še druge neknjižnǐ̌ne dejavnosti) pretesen in bolj podoben skladišcu kart, kot sodobno urejeni zbirki kaît.

Poleg kart je $\mathrm{v}$ kartografski zbirki tudi kolckcija diapozitivov in aerofotoposnetkov za posamezne predele Slovenije. Izmed kart je najobsežnejša zbirka topografskih 


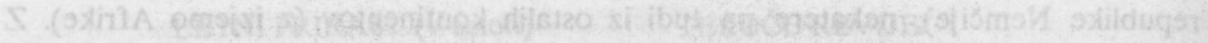

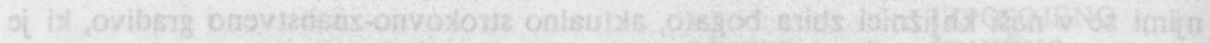

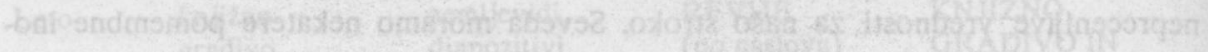

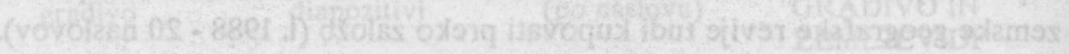

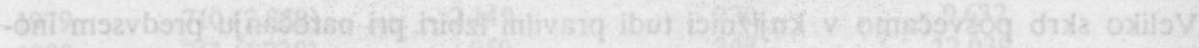

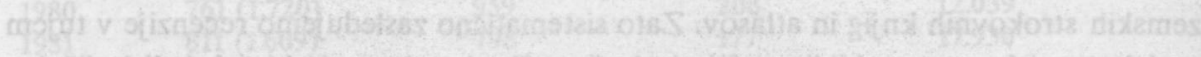

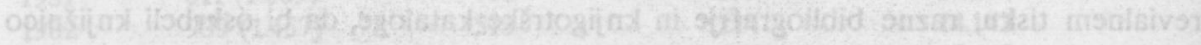

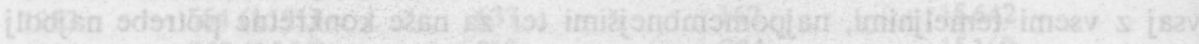

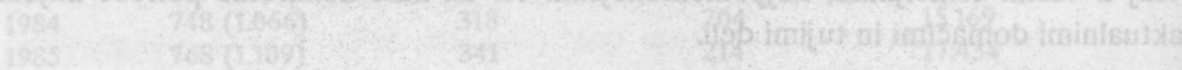
349

39107

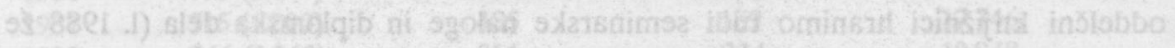

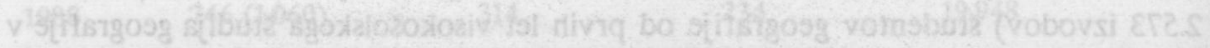

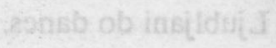

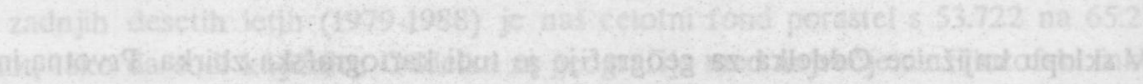

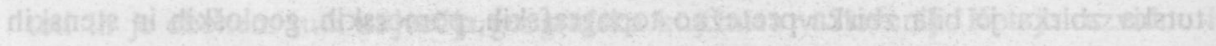

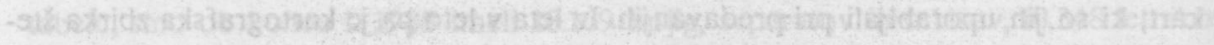

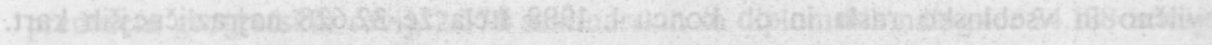

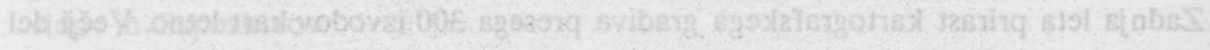

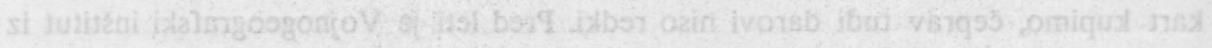

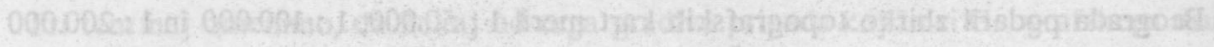

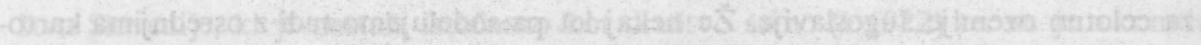

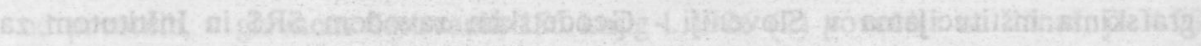

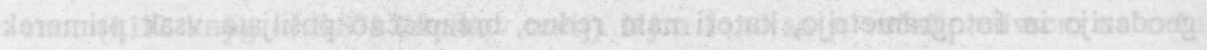

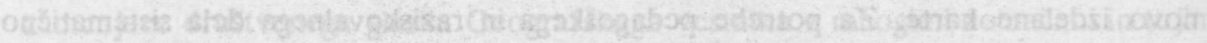

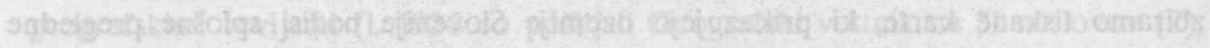

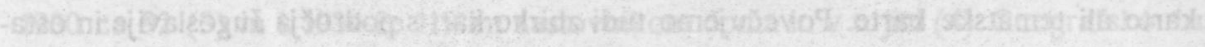

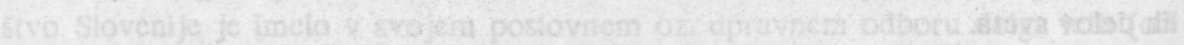

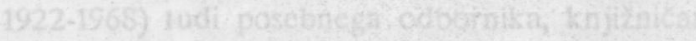

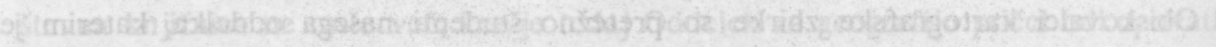

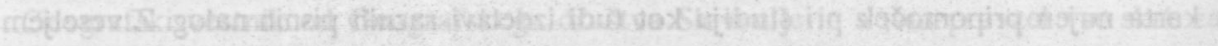

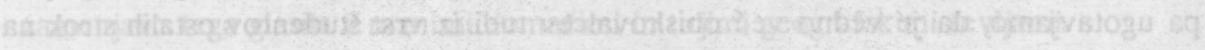

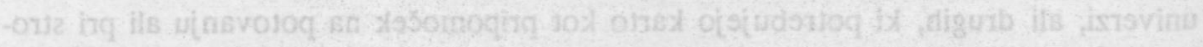

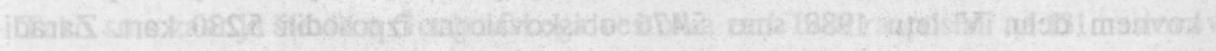

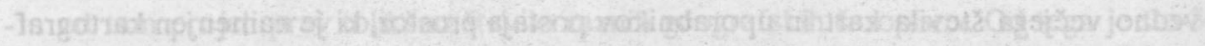

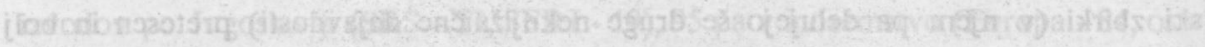

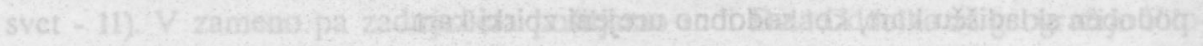

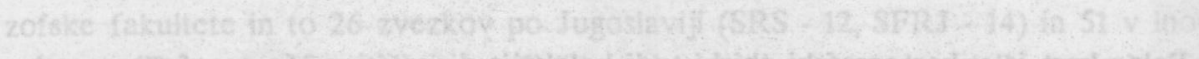

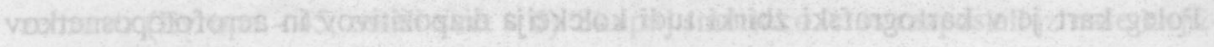

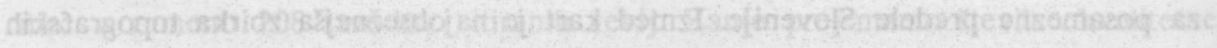

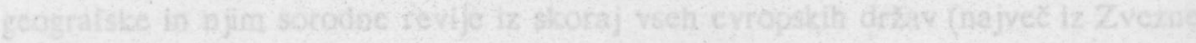




\section{ZAMENA GEOGRAFSKEGA VESTNIKA}
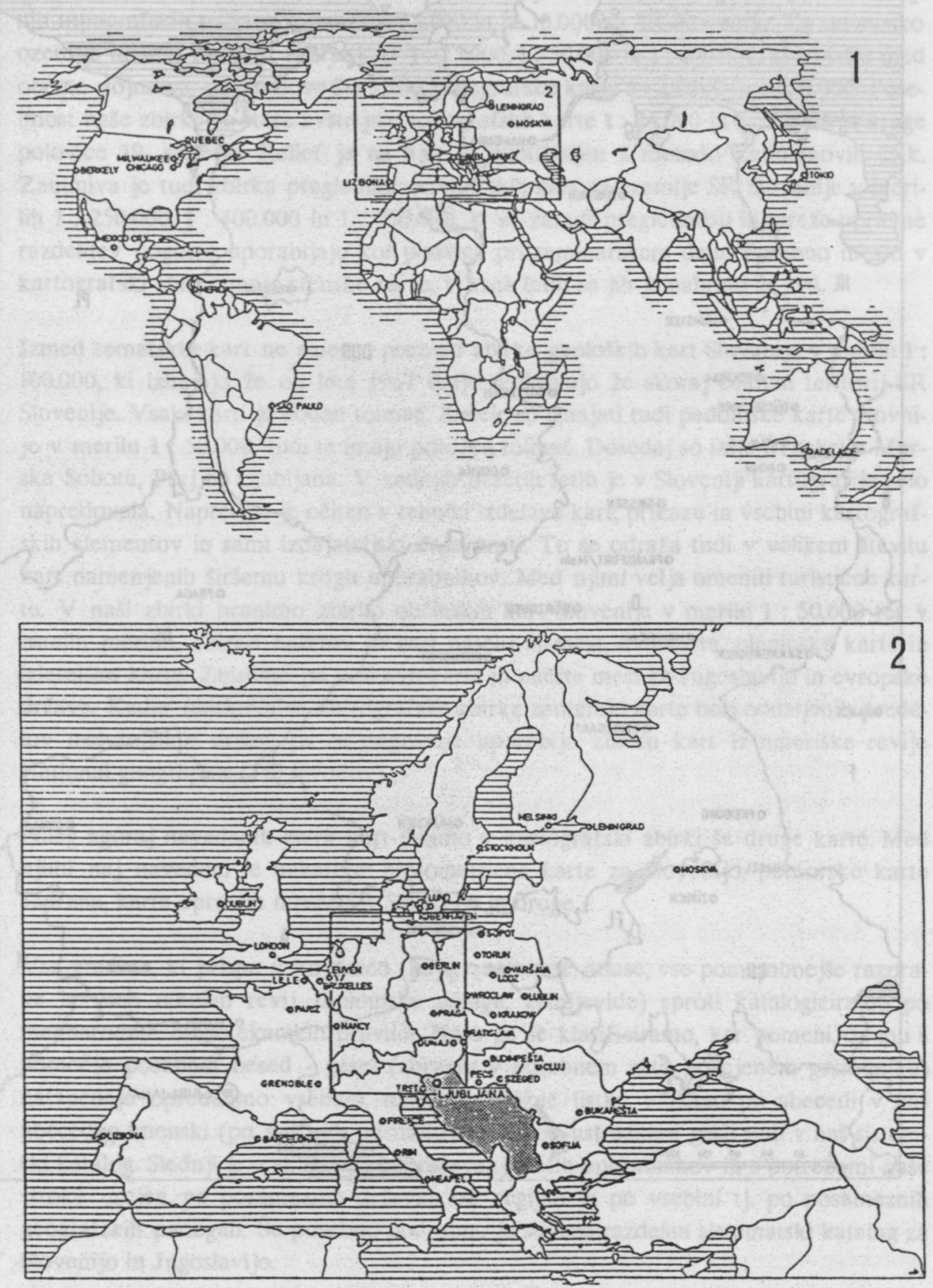


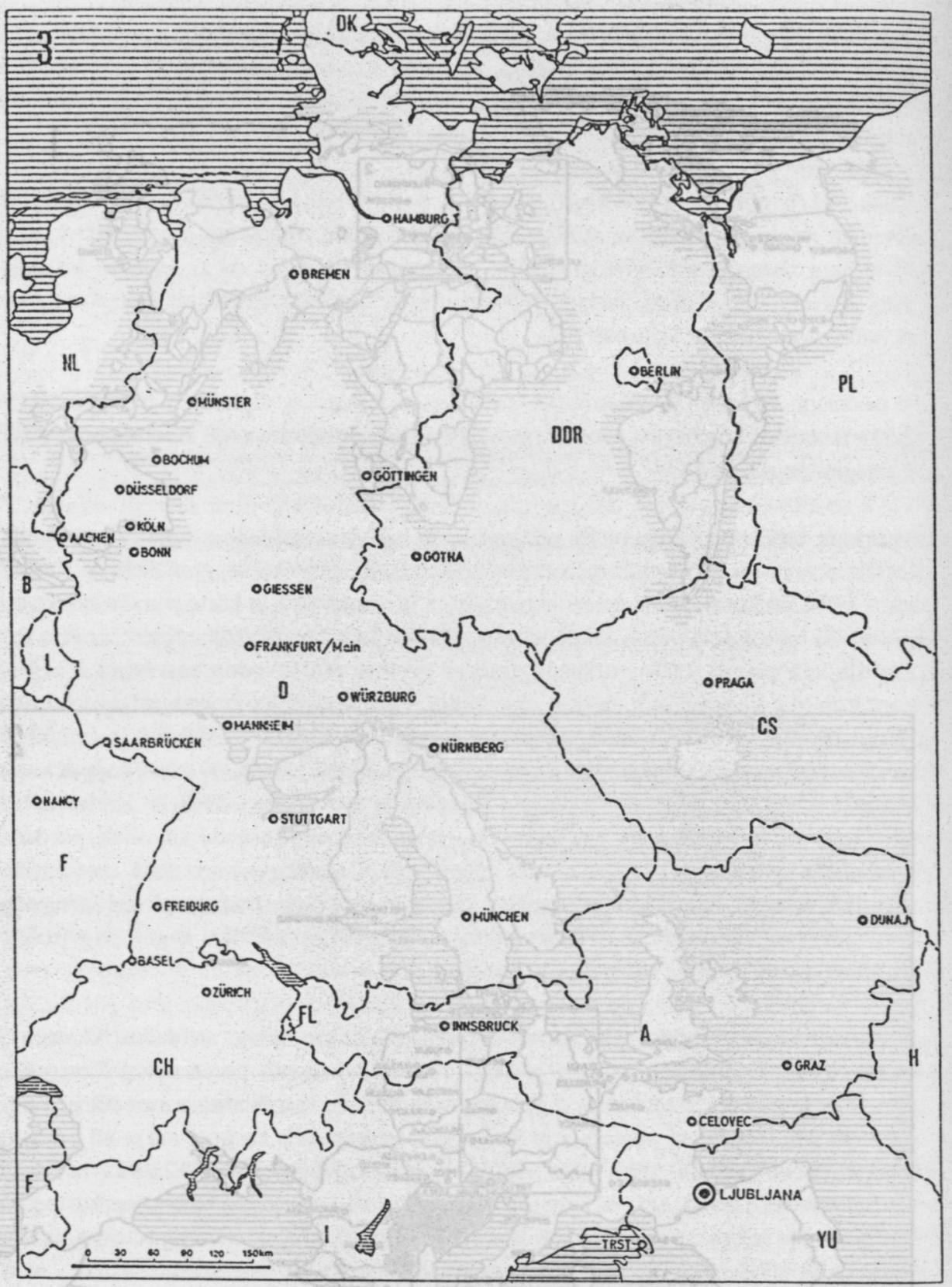


kart v merilih 1:25.000 do 1: 200.000 za ozemlje Slovenije in Jugoslavije ter temeljnih topografskih nacrtov v merilu $1: 5.000$ in $1: 10.000$ za SR Slovenijo. Za slovensko ozemlje imamo razlixne izdaje kart $1: 25.000,1: 50.000$ in $1: 100.000$, ki so izsle med obema vojnama, do najnovejsih izdaj topografske karte $1: 25.000$ in $1: 50.000$. Posebnost naše zbirke so stare avstrijske topografske karte 1:25.000 in 1:75.000 iz druge polovice 19. stoletja. Relief je na njih se upodobljen $\mathrm{z}$ metodo Lehmanovih $\mathrm{Crtk}$. Zanimiva je tudi zbirka preglednih geografskih kart za ozemlje SR Slovenije v merilih $1: 250.000,1: 400.000$ in $1: 750.000$, ki se zaradi preglednosti in mreže upravne razdelitev pogosto uporabljajo kot podloga pri seminarskem delu. Posebno mesto v kartografski zbirki imajo stenske karte. V vseh letih se jih je nabralo že 196.

Izmed tematskih kart ne smemo prezreti zbirke geoloskih kart Slovenije v merilu 1: 100.000, ki izhajajo že od leta 1967 dalje. Pokrivajo že skoraj celoten teritorij SR Slovenije. Vsaki karti je dodan tolmac. Zacele so izhajati tudi pedoloske karte Slovnije v merilu $1: 50.000$, tudi te imajo priložen tolmax. Dosedaj so izsle tri sekcije Murska Sobota, Ptuj in Ljubljana. V zadnjih desetih letih je v Sloveniji kartografija zelo napredovala. Napredek je očiten $v$ tehniki izdelave kart, prikazu in vsebini kartografskih elementov in sami izdajateljski dejavnosti. To se odraža tudi v velikem stevilu kart namenjenih Siršemu krogu uporabnikov. Med njimi velja omeniti turistǐne karte. V naši zbirki hranimo zbirko obxinskih kart Slovenije v merilu 1:50.000 ter v ostalih merilih, zbirko nacrtov in kart naselij in mest, avtokarte, planinske karte in izletniske karte. Zbiramo pa tudi avtokarte in nacrte mest za Jugoslavijo in evropske države. Kadar obiskovalce kartografske zbirke zanimajo karte bolj oddaljenih predelov neevropskih držav, pa najpogosteje uporabijo zbirko kart iz amcriške revije National geographic (145 izvodov).

Poleg zgoraj navedenih zbirk kart imamo v kartografski zbirki కe druge karte. Med njimi naj navedem le nekatere: hipsometrixne karte za Slovenijo, pomorske karte Jadrana, karte upravnc mrcže SR Slovenije in druge.

Vse gradivo, ki prispe v knjižnico (knjige, separate, atlase, vse pomembnejß̌e razprave iz vseh tekocih revij, diplomske naloge, zemljevide) sproti katalogiziramo po mednarodnih bibliotekarskih pravilih. Nato ga se klasificiramo, kar pomeni, da mu s pomoxjo posebnih besed - gesel (zbranih $\mathrm{v}$ posebnem zato prirejenem geslovniku) natančneje opredelimo vsebino, nakar kataložne listke vložimo po abecedi v naš abecedno-imenski (po avtor jih ali naslovu) in pod ustreznimi gesli tudi v nas sistemski katalog. Slednji je v skladu s povpraševanji naših uporabnikov in s potrebami naše stroke urejen po posameznih državah oz. regijah in po vsebini $t \mathrm{j}$. po posameznih geografskih panogah. Še posebno podrobno je seveda razdelan sistematski katalog za Slovenijo in Jugoslavijo. 
V knjižnici Oddelka za geografijo posvecamo veliko pozornost tudi delu z uporabniki naše literature. Knjižnica je odprta ves teden razen sobote celo dopoldne in trikrat tedensko tudi popoldan ( $v$ torek, sredo in cetrtek), skupaj torej kar 48 ur na teden. Obiskovalcem knjižnice pomagamo $\mathrm{s}$ strokovnimi nasveti $\mathrm{v}$ zvezi $\mathrm{z}$ iskanjem raznih podatkov, strokovne literature in podobno. Izposoja na dom in $\mathrm{v}$ citalnico je zadnja leta nekaj presegaia 17.000 enot knjižniðnega gradiva in kart, zadnje leto pa je predvsem zaradi intenzivnejšega, bolj seminarskega dela s slusatelji prvega letnika, kjer je studentov največ, poskocila kar na 19.948 izvodov.

Študente - novince vsako leto jeseni sprejmemo v naŠih prostorih, jim ob tem razkažemo našo knjižnico, obenem pa jih seznanimo s katalogi (naši katalogi obsegajo namre` kar 200 predaičkov) ter pokažemo, kako in kje je v njih treba iskati zaželeno literaturo. Ob tem obisku dobijo študenti tudi poseben "vodie", v katerem najdcjo osnovne podatke o naši oddelと̌ni knjižnici ter čisto tehnične napotke o njenem delovanju. Da bi jih že na zað̌etku študija Še intenzivneje seznanili $\mathrm{z}$ naŠmi katalogi in $\mathrm{z}$ iskanjem literature $\mathrm{v}$ njih, morajo novinci pred izpitom iz Uvoda $\mathrm{v}$ geografijo $\mathrm{v} 1$. letniku opraviti pri nas iz tega tudi posebno pismeno vajo.

Vseskozi pa smo želeli tudi sproti seznanjati naše uporabnike $\mathrm{z}$ novo geografsko literaturo. $\mathrm{V}$ ta namen že vrsto let izdajamo meseð̌ni knjižnični bilten s seznamom v tem mesecu prispelih $\mathrm{knjig}$, pomembnejsih in za nas se posebno aktuainih razprav iz prispelih revij ter zemljevidov. Ta seznama prejmejo pedagoł̌ko-znanstveni delavci našga oddelka, posiljamo pa ga tudi geografom po ostalih geografskih in drugih institucijah ter zavodih v Ljubljani in Mariboru, $v$ zadnjem Casu pa na njinovo željo tudi trem profesor̈jem geografije $\mathrm{z}$ univerze $\mathrm{v}$ Celovcu. Mesečno razposljemo okoli 40 izvodov biltena. Hkrati pa bibliotekarke objavljamo porozila o nekaterih novih slovenskih in jugoslovanskin knjigah in revijah v poljudno-geografskem Casopisu, Gcografskem obzorniku.

Med dejavnosti raše knjižnice sodi tudi sodelovanje pri pripravi raznih knjižnih razstav, bodisi v okviru Filozofske fakultete, bodisi ob zborovanjih slovenskih geografov ali drugih prireditvah v okviru dejavnosti Zveze geografskih društev Slovenije. Bibliotekarke pa se aktivno udejstvujemo tudi na bibliografskem podrox ju. Tako so bile doslej objavljene nasiednje naše geografske bibliografije: Tatjana Šifrer: Slovenska geografska bibliografija za obdobje 1960-1965, Ljubljana 1966 (skupaj z Miro Lojk); Slovenska geografska bibliografija za leto 1967, Ljubljana 1968) (skupaj z Miro Lojk); Bibliografija del o industrijski geografiji Jugoslavije 1945-1978, Ljubljana 1985. Janja Turk (roj. Miklavc): Bibliografija ožje Dolenjske in Bele krajine (1945-1984), v: Dolenjska zemlja in ljudje, Ljubljana 1984 (skupaj z Mojco Zupanðic); Bibliografija Geografskega obzornika I (1954) - XXXI (1984), Geografski obzornik 1985; Bibliografija v tujini objavljenih del clanov Oddelka za geografijo 1945-1984, Dela Oddelka za geografijo Filozofske fakultete Univerze Edvarda Kardelja v Ljubljani 1985. 
V knjižnici Oddelka za geografijo smo v zadnjih letih zaposlene štiri knjižnǐ̌ne delavke: bibliotekarski svetovalec Tat jana Šifrer (od 1. 1954, upokojena 1. 1989), bibliotekar specialist Janja Turk (od 1. 1979), bibliotekarki Mojca Dolgan-Petrix (od I. 1987) in Ida Knez (od l. 1989) ter višja knjižna manipulantka Toncka Abbad (od 1. 1972).

\section{LITERATURA}

Gavazzi A., 1922: Geografijski institut sveuxilista u Ljubljani. - Nastavni vjesnik, Zagreb: knj. XXX (1922), str. 536-539.

Geografski vestnik 1926, L jubljana: II (1926), str. 58, 172.

Geografski vestnik 1929-1930, Ljubljana: V-VI (1929-30), str. 230.

Geografski vestnik 1934, Ljubljana: X (1934), str. 223-228.

Turk J., 1987: Kartografska dejavnost v Sloveniji (1977-1987) in njena predstavitev v geografski periodiki, Ljubljana. 